\title{
PRIMARY BILIARY CIRRHOSIS AND ANKYLOSING SPONDYLITIS, A RARE ASSOCIATION
}

Kenéz Emese - Katalin, Balló István, Gáspár Enikő, Biró Anna Julianna

\begin{abstract}
Primary biliary cirrhosis is an autoimmune liver disease, characterized by the progressive destruction of the small intrahepatic bile duct epithelial cells and the presence of antimithocondrial antibodies (AMA). Ankylosing spondilitis is a systemic, inflammatory, progressive disease, which usually affects the joints of the spine and the sacroiliac joints. The association of these two is very rare, in literature we found only one single study published in 1994, which describes the occurrence of primary biliary cirrhosis accompanying ankylosing spondylitis in a male patient. The aim of our study is to present the case of our patient, who had ankylosing spondylitis and has developed primary biliary cirrhosis. Our patient has ankylosing spondylitis with peripheral joint involvement, so according to the guidelines we initiated treatment with Sulfasalazine. We know from the literature about the hepatotoxicity of Sulfasalazine in some cases, so within each follow-up examination we monitored the liver function tests, and we also performed complete blood counts. The treatment of ankylosing spondylitis is challenging in this case due to the hepatotoxicity of the medications. Besides Sulfasalazine, our patient continued the treatment for primary biliary cirrhosis (ursodeoxycholic acid with hepatoprotective drugs in higher doses).
\end{abstract}

Key words: Primary biliary cirrhosis, ankylosing spondilitis, Sulfasalazine, hepatotoxic

\section{Rezumat}

Ciroza biliară primară este o boală hepatică autoimună, caracterizată prin distrugerea progresivă a celulelor epiteliale ale căilor biliare intrahepatice şi prin prezenţa de anticorpi antimitocondriali (AAM). Spondilita anchilozantă este o boală inflamatorie sistemică, progresivă, care afectează de obicei articulaţiile coloanei vertebrale şi articulaţiile sacroiliace. Asocierea acestor două boli este foarte rară, în literatură am găsit doar un singur articol publicat în 1994, care descrie apariţia cirozei biliare primare concomitent cu spondilita anchilozantă la un pacient de sex masculin. Scopul acestei prezentări de caz este să prezentăm cazul pacientei noastre la care, pe lângă spondilita anchilozantă, s-a asociat şi ciroză biliară primară. Datorită formei periferice a spondilitei anchilozante, conform ghidurilor am iniţiat tratament cu Sulfasalazină. După cum ştim din literatură, sulfasalazina poate să fie hepatotoxică în unele cazuri, astfel în cadrul fiecărui control am monitorizat parametrii hepatici, împreună cu hemoleucograma. Tratarea spondilitei anchilozante este dificilă în acest caz, pentru că majoritatea medicamentelor folosite sunt hepatotoxice. Pe lângă Sulfasalazină, pacienta şi-a continuat tratamentul administrat pentru ciroza biliară primară (acidul ursodeoxicolic cu hepatoprotectoare în doze mai mari).

Cuvinte cheie: ciroza biliară primară, spondilită anchilozantă, sulfasalazină, hepatotoxic. 


\section{INTERNAL}

\section{Clinical cases}

\section{Introduction}

Primary biliary cirrhosis (PBC) is an autoimmune liver disease characterized by the presence of very specific serum antimitochondrial antibodies (AMA), and by the progressive destruction of intrahepatic bile duct epithelial cells, resulting in chronic cholestasis and fibrosis, which may lead to liver cirrhosis and subsequent hepatic impairment (1).

It has a prevalence of approximately $150-300$ $/ 1,000,000$ patients and involves women in $90 \%$ of cases (2). Diagnosis of primary biliary cirrhosis may be suspected in the presence of chronic cholestasis, excluding other hepatic diseases. The suspected diagnosis is based on cholestatic liver tests, but is confirmed by the presence of AMA (3).

Primary biliary cirrhosis may be associated with several autoimmune diseases, including Sjögren's syndrome in $70 \%$ of patients, autoimmune thyroid disease in about $10 \%$ (4), systemic sclerosis in $15 \%$ of cases (5), and rarely rheumatoid arthritis between 1.8 and $5.6 \%$ (6). Ankylosing spondylitis (AS) is a progressive chronic systemic inflammatory disease that affects the joints of the spine, sacroiliac joints, and surrounding soft tissues. Often, the inflammatory process begins at the sacroiliac joints, subsequently involving the other spinal segments. Inflammation will be followed by fibrosis and then by bone ankylosis, creating a rigid spinal column $(7,17)$. The HLA - B27 phenotype is present in $90 \%$ of patients with ankylosing spondylitis $(7,8)$. The association of primary biliary cirrhosis with ankylosing spondylitis is very rare, in literature we have found only one published case, in 1994 (9). In this case study we present the case of a patient with ankylosing spondylitis associated with primary biliary cirrhosis.

\section{Case presentation}

A 56-year-old female patient first admitted to the Rheumatology Clinic in Târgu Mureş in February 2016, with the following complaints: right gonalgia with mixed character, dorsalgias, inflammatory lumbar pain, pain in the chondrosternal joints, morning stiffness for about 10 minutes.

\section{Disease history}

The patient is known with ankylosing spondylitis since 1990, HLA - B27 positive, diagnosed with iridocyclitis in 1998. In 2014, she was diagnosed with primary biliary cirrhosis due to elevated levels of alkaline $\mathrm{phosph}$ a t a s e ( A L P) a nd Y glutamyltransferase (GGT), AMA and ANA positive.

The patient was also known to have hepatic hemangioma, chronic urticaria, grade 2 
essential hypertension, asymptomatic hyperuricaemia, cortical and pyelocaliceal renal cysts, cholecystectomy, allergic rhinitis and drug allergy to Diclofenac and Mydocalm.

\section{Physical examination}

The local examination revealed: radiocarpal joint painful upon palpation bilaterally, scapulohumeral joint with acromioclavicular points and bicipital groove painful upon palpation, right scapulohumeral motion 150/150/60잉 left: 150/160/60ㅇ, short neck, anteprojected head, accentuation of dorsal kyphosis with flattening of D4-D5, leftconvex scoliosis, reduction of lumbar lordosis in the lower part, contracture of the upper trapezius, painful bilateral Arnold points, contracture of paravertebral muscles, cervico-dorso-lumbar sensitivity upon percussion, limitation of cervical and lumbar lateral inflection, Schober $10 / 15 \mathrm{~cm}$, pain upon percussion of the right sacroiliac joint, warm right knee, pain upon palpation of the joint interline, legs with Gaenslen slightly positive bilaterally. ITA right/left: $11 / 12 \mathrm{~cm}$, IOP: 0, IMS: 0, Ott: $30 / 30.5 \mathrm{~cm}$, Stibor: $49 / 52 \mathrm{~cm}$, lateral lumbar inflexion right/left: $6.5 / 6 \mathrm{~cm}$, IDS: $18 \mathrm{~cm}$. IETM: $95 / 97.5 \mathrm{~cm}$. BASDAI: 6.8, BASFI: 6.0, VAS: 90.

\section{Paraclinical examinations}

Pelvic radiography for sacroiliac joints reveals sacroiliitis stage III. Radiography of the D12-L2 vertebral column reveals the accentuation of dorsal kyphosis, reduction of lumbar lordosis, L1-L3 square vertebrae, lumbar "shiny corners" aspect, osteoporosis of the vertebral bodies, decrease of anterior height of D11-12 vertebral bodies. Laboratory tests: ESR $64 \mathrm{~mm} / \mathrm{h}$, CRP 3.214 $\mathrm{mg} / \mathrm{dL}$ (NV <0.33 mg / dl), Hgb $13.0 \mathrm{~g} / \mathrm{dL}$; Hct 37.4\%, WBC $5640 / \mathrm{mm}^{3}$; PLT 291,000/ $\mathrm{mm}^{3}$, Glycaemia $85.6 \mathrm{mg} / \mathrm{dL}$, Creatinine $0.62 \mathrm{mg} / \mathrm{dL}$, GOT 20.6 U / L, GPT $14.8 \mathrm{U} / \mathrm{L}$, alkaline phosphatase $197 \mathrm{U} / \mathrm{L}, \mathrm{LDH} 145 \mathrm{U}$, CPK $68 \mathrm{U} / \mathrm{L}$, total serum Ca $2.61 \mathrm{mmol} / \mathrm{L}$, uric acid: $6.1 \mathrm{mg} / \mathrm{dl}$, FT4 $1.17 \mathrm{ng} / \mathrm{mL}$, TSH 3.40 $\mu \mathrm{U} / \mathrm{mL}$, total protein $7.20 \mathrm{~g} / \mathrm{dL}, \mathrm{Na} / \mathrm{K}$ 142.90 / $3.50 \mathrm{mmol} / \mathrm{L}, \mathrm{CIC} 90 \mathrm{FU}$, cryoglobulins negative, ASLO negative; serum protein electrophoresis: A / G - 1.22 (NV: 0.8-1.2), alpha 1 - 3.9\% (VN: 1-3.2\%), albumin-54.9\% (NV: 59.8-72.4\%), alpha 2 15\% (NV:7.4 - 12.6\%), beta1 - 13.9\% (NV: 5 $8.6 \%)$, gamma - 12.3 .

\section{Diagnosis}

We have established the diagnosis of ankylosing spondylitis in the mixed form, sacroiliac stage III with extraarticular manifestations, according to anamnestic data (patient known with ankylosing spondylitis since 1990, HLA - B27 positive and iridocyclitis in 1998) of the objective exam data (tests and index specific for ankylosing spondylitis), paraclinic data (pelvic radiography for sacroiliac joints reveals sacroillitis stage III), and laboratory tests (ESR and CRP increased).

Diagnosis of primary biliary cirrhosis is supported by the constant increase of cholestatic analyzes (ALP, GGT) and by the presence of AMA and ANA known from anamnestic data.

\section{Differential diagnosis}

We have performed the differential diagnosis with other diseases:

a) Reactive arthritides - as far as we know, our patient did not have any Yersinia, Salmonella, Shigella, Klebsiella, 
INTERNAL MEDI

Clinical cases

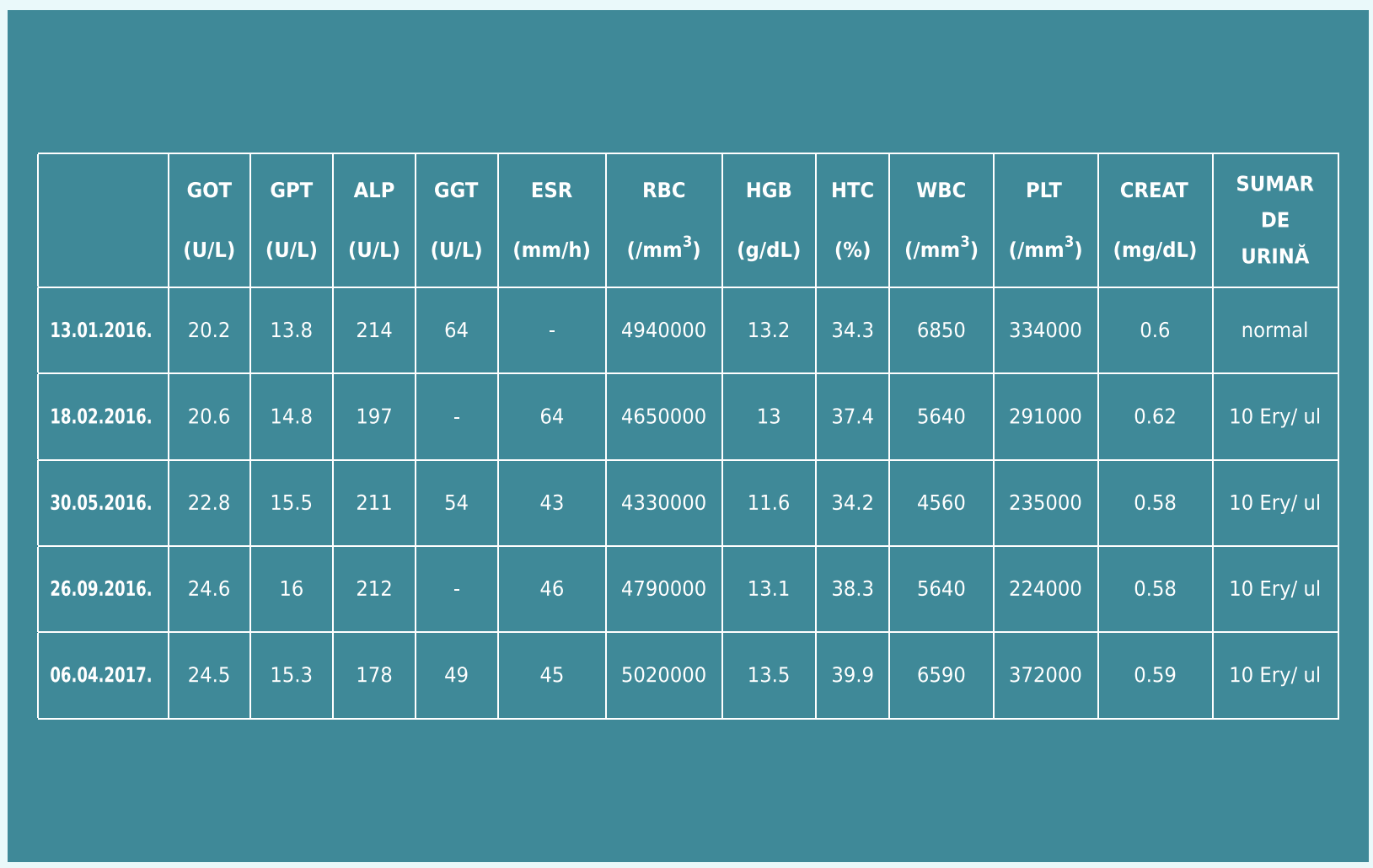

Table 1. Laboratory tests performed at the beginning and during Sulfasalazine administration

Campylobacter, Chlamydia trachomatis, Chlamydia pneumoniae infection;

b) Enteropathic arthritides - the patient had no symptoms suggestive of ulcerative colitis or Crohn's disease;

c) Psoriatic arthritis - the patient does not have skin lesions that advocate the diagnosis of psoriatic arthritis;

d) Septic arthritides - the patient is not known to have had TB;

e) Degenerative arthritides: spondylosis, discopathies - the presence of sacroilitis and inflammatory syndrome (which does not characterize spondylosis and discopathies);

f) Scheuermann's disease - Schmorl's nodes were not found in our patient;

g) Primary tumors or metastases - we did not find signs suggestive for these diseases;

h) Multiple myeloma - we have not found laboratory tests that correlate with this condition. 


\section{Treatment}

Due to the mixed nature of ankylosing spondylitis (predominantly peripheral), and with the consent of the treating gastroenterologist, we decided to initiate treatment with Sulfasalazine according to the guidelines: Sulfasalazine $500 \mathrm{mg}$ 1st week 0 0 - 1 / day, 2nd week 1 - 0 - 1 / day, 3rd week 1 0 - 2 / day, 4th week and subsequently 2 - 0 - 2 / day, with strict monitoring of ESR, CRP, CBC, GOT, GPT, ALP, GGT, creatinine, periodic urinalysis. In 2014, when primary biliary cirrhosis was diagnosed, the treating gastroenterologist initiated Ursofalk (ursodeoxycholic acid) $250 \mathrm{mg} 0-0-3 /$ day, along with Silimarine $150 \mathrm{mg} 0$ - 1 - 0 / day, Essentin forte $2 \times 1$ /day, treatment which the patient continues to this day. Within each follow-up examination we monitored the laboratory tests that are detailed in Table 1. Within the next follow-up examinations, due to joint symptomatology and laboratory tests (ESR, CRP increased continuously) we needed to gradually increase the dose of Sulfasalazine $500 \mathrm{mg}$ to $3 \mathrm{~g} /$ day. As a result of the present articular symptoms with inflammatory syndrome continuously present (ESR, CRP increased) and with the maximum dose of Sulfasalazine reached, the next step in the treatment schedule is the initiation of biological therapy (TNF-alpha inhibitors). According to the guidelines, biological therapy is initiated when the disease is active despite the use of Sulfasalazine for more than 4 months. However, the patient refuses biological therapy. Thus, the patient remains on treatment with Sulfasalazine, ursodeoxycholic acid and hepatoprotectors.

\section{Discussions}

Primary biliary cirrhosis is often associated with other autoimmune diseases: Sjögren's syndrome, autoimmune thyroid disease (4), systemic sclerosis (5) and, more rarely, rheumatoid arthritis (6). We found a single article in the literature (1994) describing a case of ankylosing spondylitis associated with primary biliary cirrhosis. Thus, the prevalence of primary biliary cirrhosis associated with ankylosing spondylitis is unknown.

In the peripheral form of ankylosing spondylitis, Sulfasalazine treatment is used according to the guidelines $(10,11,12)$. Sulfasalazine is administered orally. In the colon, Sulfasalazine is cleaved by bacterial flora into 5-aminosalicylic acid (Mesalazine) and Sulfapyridine. Mesalazine remains in the colon and is not absorbed into the bloodstream. Most of Sulfapyridine is absorbed from the colon and is excreted in the urine. Side effects of Sulfasalazine include nausea, vomiting, diffuse abdominal pain, headache, altered general condition, haemolytic anemia, aplastic anemia, leucopenia, neutropenia, agranulocytosis (very rarely), methemoglobinemia, rash, hepatic or pulmonary dysfunction $(13,18)$. Acute and clinically relevant hepatic injury, secondary to Sulfasalazine treatment, may occur in 1 in 1,000 patients.

Most cases occur in the first month of treatment with Sulfasalazine as a hepatocellular or cholestatic Iesion. Approximately $25 \%$ of patients develop jaundice and a certain proportion rapidly develop liver failure $(14,15)$. In another study, the prevalence of Sulfasalazine-induced hepatitis was about $0.4 \%$. Two patients developed hepatic impairment - the estimated rate is approximately 1.4 per 1,000 treated people (16).

We have introduced Sulfasalazine in the therapy of our patient with gradual dose escalation and dose adjustment according to the patient's symptoms. Within each follow- 
up examination, we monitored the biological parameters for liver function (GOT, GPT, ALP, GGT), complete blood count, and urinalysis. Table 1 shows all the patient's laboratory tests performed during the follow-up examinations. We note that only the cholestasis parameters (ALP and GGT) have been constantly elevated - which correlates with primary biliary cirrhosis, and the erythrocyte sedimentation rate (ESR) - as a result of the inflammatory syndrome of the ankylosing spondylitis.

In the patients' case, it would be necessary to initiate biological therapy with TNF-alpha inhibitors (ankylosing spondylitis is active despite treatment with Sulfasalazine at the maximum dose for more than 4 months), but the patient refuses it and thus we maintain her on treatment with Sulfasalazine.

\section{Conclusions}

With this paper we wanted to present the case of a patient diagnosed with ankylosing spondylitis in 1990, who after 24 years also developed primary biliary cirrhosis. We have introduced Sulfasalazine to treat and relieve the symptoms of ankylosing spondylitis, well tolerated under strict monitoring of liver parameters, as it is known from the literature that Sulfasalazine may be hepatotoxic.

The specificity of the case is the difficulty of treating ankylosing spondylitis in the presence of primary biliary cirrhosis because the drugs used in the treatment of ankylosing spondylitis are usually hepatotoxic (NSAIDs diclofenac, methotrexate, TNF-alpha inhibitors, but also sulfasalazine). Therefore, strict follow-up examinations are required with laboratory tests. Clinical trials based on the association of ankylosing spondylitis with primary biliary cirrhosis are required to be conducted in the future.

\section{Bibliography}

1. C.L.Bowlus, M.E.Gershwin - The Diagnosis of Primary Biliary Cirrhosis, Autoimmunity Reviews, Volume 13, Issues 4 - 5, April - May 2014, pg.441 - 444.

2. S.C.Hauser, D.S.Pardi, J.J.Poterucha - Mayo Clinic Gastroenterology and Hepatology Board Review, Third Edition, Mayo Clinic Scientific Press And Informa Healthcare USA, Inc, 2008, Rochester, MN, pg.377-381

3. K. D. Lindor, M. E. Gershwin, R. Poupon, M. Kaplan, N. V. Bergasa, and E. J. Heathcote-Primary biliary cirrhosis, AASLD Hepatology, AASLD Practice Guidelines, Volume 50, Issue 1, 2009, pg.291- 308.

4. N. Bekki, S. K. Bae, S. Yoshizawa, A. Shiota, T. Gushima, J. Motoshita, S. Shimoda, Y. Aiba, A. Komori, M. Nakamura, K. Takahashi - A case of primary biliary cirrhosis in a patient with rheumatoid arthritis, Clinical Case Reports 2016; Volume 4, Issue 1, pg. 90-94

5. S. Abraham, S. Begum, D .Isenberg - Hepatic manifestations of autoimmune rheumatic diseases, Annals of the Rheumatic Diseases, 2004, Volume 63, Issue 2, pg.123-129.

6. C. Caramella, J. Avouac, Ph. Sogni, X. Puéchal, A. Kahan, Y. Allanore - Case report: Association between rheumatoid arthritis and primary biliary cirrhosis, Joint Bone Spine 2007, 74(3), pg.279- 281

7. Reumatológia Jegyzet, Prof.Dr.Lia Georgescu, Litografia UMF Tirgu Mures, 2010, pg. 152 - 170

8. S. Gonzaler-Roces, M. V. Alvarez,S. Gonzalez, A. 
Dieye, H. Makni, 0. G. Woodfield, L. Housan, V. Konenkov, M. C. Abbadi, N. Grunneta, E. Cotol, C. Lopez-tarreal HLA-B27 polymorphism and worldwide susceptibility to ankylosing spondylitis, Tissue Antigens, Volume 49,Issue 2,1997, pg. 116-123.

9. C.A. Vargas, R. Medina, C.E. Rubio, E.A. Torres Primary biliary cirrrhosis associated with Ankylosing spondylitis, Journal of Clinical Gastroenterology, 1994, 18(3), pg.263 - 264.

10. J. Zochling, D. van der Heijde, R. Burgos-Vargas, E. Collantes, J. C. Davis Jr, B. Dijkmans, M. Dougados, $P$. Ge'her, R. D. Inman, M. A. Khan, T. K. Kvien, M. LeirisaloRepo, I. Olivieri, K. Pavelka, J. Sieper, G. Stucki, R. D. Sturrock, S. van der Linden, D. Wendling, H. Bo"hm, B. J. van Royen, J. Braun - ASAS/EULAR recommendations for the management of ankylosing spondylitis, Annals of the Rheumatic Diseases, 2006;65(4), pg:442 - 452.

11. J. Braun, R. van den Berg, X. Baraliakos, H. Boehm, R. Burgos-Vargas, E. Collantes-Estevez, H. Dagfi nrud, B. Dijkmans, M. Dougados, P. Emery, P. Geher, M. Hammoudeh, R.D. Inman, M. Jongkees, M.A. Khan, U. Kiltz, T.K. Kvien, M. Leirisalo-Repo, W.P. Maksymowych, I. Olivieri, K. Pavelka, J. Sieper, E. Stanislawska-Biernat, D. Wendling, S. Özgocmen, C van Drogen, B.J. van Royen, D. van der Heijde - 2010 update of the ASAS/EULAR recommendations for the management of ankylosing spondylitis, Annals of the Rheumatic Diseases, 2011; Volume 70, Issue 6, pg.896- 904.

12. C.L. Kohema, A. B. Bortoluzzob, C. R. Gonçalvesc, J. A. Braga da Silvad, A. C. Ximenese, M. B. Bértolo f, S.L.E.
Ribeirog, M. Keisermanh, R. Menini, T. L. Skarej, S. Carneirok, V. F. Azevedol, W. P. Vieiram, E. N. Albuquerquen, W. A. Bianchio, R. Bonfigliolip, C. Campanholoq, H. M. S. Carvalhor, I. Pereira da Costas, A. L. B. Pinto Duartet, N. H. Leiteu, S. A. L. Limaw, E. S. Meirellesx, I. A. Pereiray, M. M. Pinheiroz, E. Polito, G. G. Resende, F. A. C. Rocha, M. B. Santiago,M. de Fátima L. C. Sauma, V. Valim, P. D. Sampaio-Barros - Profile of the use of disease modifying drugs in the Brazilian Registry of Spondyloarthritides, Revista Brasileira de Reumatologia, 2013, 54(1), pg.33-37.

13. S. L. Taffet, K. M. Das-Sulfasalazine. Adverse effects desensitization, 1983, Volume 28, Issue 9, pg. 833 - 842.

14. G. P. Aithal-Hepatotoxicity related to antirheumatic drugs, Nature Reviews Rheumatology, 2011, Volume 7, pg. $139-150$.

15. A. Pandit, T. Sachdeva, P. Bafna - Drug - Induced Hepatotoxicity: A Review, Journal of Applied Pharmaceutical Science 2012, 02 (05); pg.233-243

16. P. Jobanputra, R. Amarasena, F. Maggs, D. Homer, S. Bowman, E. Rankin, A. Filer, K. Raza, R. Jubb Hepatotoxicity associated with sulfasalazine in inflammatory arthritis: A case series from a local surveillance of serious adverse events, BMC Musculoskeletal Disorders 2008, 9:48.

17. R. Ionescu - Esenţialul în reumatologie, capitolul Spondilita anchilozantă, ed.Amaltea, Bucureşti, 2007, pg. $281-292$.

18. Szekanecz Z. - Reumatológiai gyógyszeres terápia, Editura Medicina, Budapesta, 2009, pg. 75 - 76. 